\title{
A Study of the Effects of Architectural Forms on Sound Quality in Church Buildings
}

\author{
Ediae O.J. ${ }^{1}$, Enoma E.P. ${ }^{2, *}$, Igbogbo O.S. ${ }^{1}$, Ezema I. C. ${ }^{1}$ \& Ekhaese E.N. ${ }^{1}$ \\ ${ }^{1}$ Department of Architecture, Covenant University, Otta, Nigeria. \\ ${ }^{2}$ Department of Architecture, University of Benin, Benin City, Nigeria \\ Corresponding Author: *paul.enoma@uniben.edu
}

\begin{abstract}
Acoustics in churches design is concerned with the impact of sound on both the worshippers and the building as well. The aim of this study is to investigate sound audibility and quality with the use of acoustic materials and most appropriate architectural form. Qualitative and case study approach were adopted, the qualitative method involves the collection of narrative data in a natural setting, with a view to gaining insight. While the case study involved an intensive study of specific phenomena through investigations. These methods were chosen due to the nature of this research, personal observation and interviews were extensively carried out. Research shows that, architectural forms are special vaccines necessary to achieve quality of sound in churches and large halls in general.
\end{abstract}

Keywords: Architectural Form, Acoustic, Sound Quality, Church Buildings

\subsection{Introduction}

Christianity has mistakenly been defined and described as a religion in which morality and beliefsystem in correspondence to the book are regarded as the basis of the role-playing and problem-solving of the Christian life (Fowler, 2008). Fowler (2008) also states that Christianity refers to the external, on-going reality of the life and work of the living Lord Jesus, who by the spirit provides the dynamic of divine presence and function within receptive Christian individuals and communities.

Taking a cue from the bible, Acts 11:26 states that "the disciples were called Christians first in Antioch. This gives a very clear definition of being a Christian. Tracing the history of Christians, Watson (1978) explains that for the first two centuries, the Church met in small groups in the homes of its members, apart from special gatherings in public lecture halls or market places, where people could come together in much larger numbers. Poruciuc (2000) also explains that over time, the need to house this group of believers became apparent, which gave birth to Church Architecture. Church Architecture is also known as Religious Architecture. Church buildings were initially small but overtime large church buildings began to evolve after the acquisition of bigger land and skilled labour. This helped in achieving a better building that is aesthetically pleasing and large enough for the congregation. Till date, these Church buildings reflect the character and needs of the members. Often times, the building character helps to identify the Church denomination such as Anglican, Catholic, or Pentecostal. This is why Bruce (2004) posits that when designing a Church, these questions were asked and must still be asked today, how does our faith and worship shape our building? How do we determine our needs? How do we find the right people to design and build this building? And lastly what kind of resources would be required to get it built? These above questions if answered correctly reflect the vision of the Church, and also help in generating the style of the building.

As Churches became large, it became difficult for everyone to hear the preacher clearly. This problem became partially solved with the use of microphones and speakers. However, this equipment did not come without its own problem. According to Noxon (2001), this problem usually begins with complaints like "we just cannot hear what is going on". This problem has to do with Church acoustics. Watson (1925) explains that the acoustics of Churches is much of a mystery to most people, he also stated that, sound is supposed to act in a curious way no one can predict. Noxon (2001) defines acoustics 
as the science that studies the waves that are conducted through matter due to the motion of the matter. Usually air is the material that most people think of when it comes to acoustic waves. But acoustic waves exist in all matter. Architectural acoustics is the study of acoustics when the air is contained in a room. Church acoustics is a sub-division of architectural acoustics.

\subsection{Architectural Forms}

This refers to the various shapes adopted by architects to showcase the design of buildings. In Churches, certain shapes are usually considered considering the nature of worship and the denomination of the Church. Below are samples of commonly used architectural form for Churches.

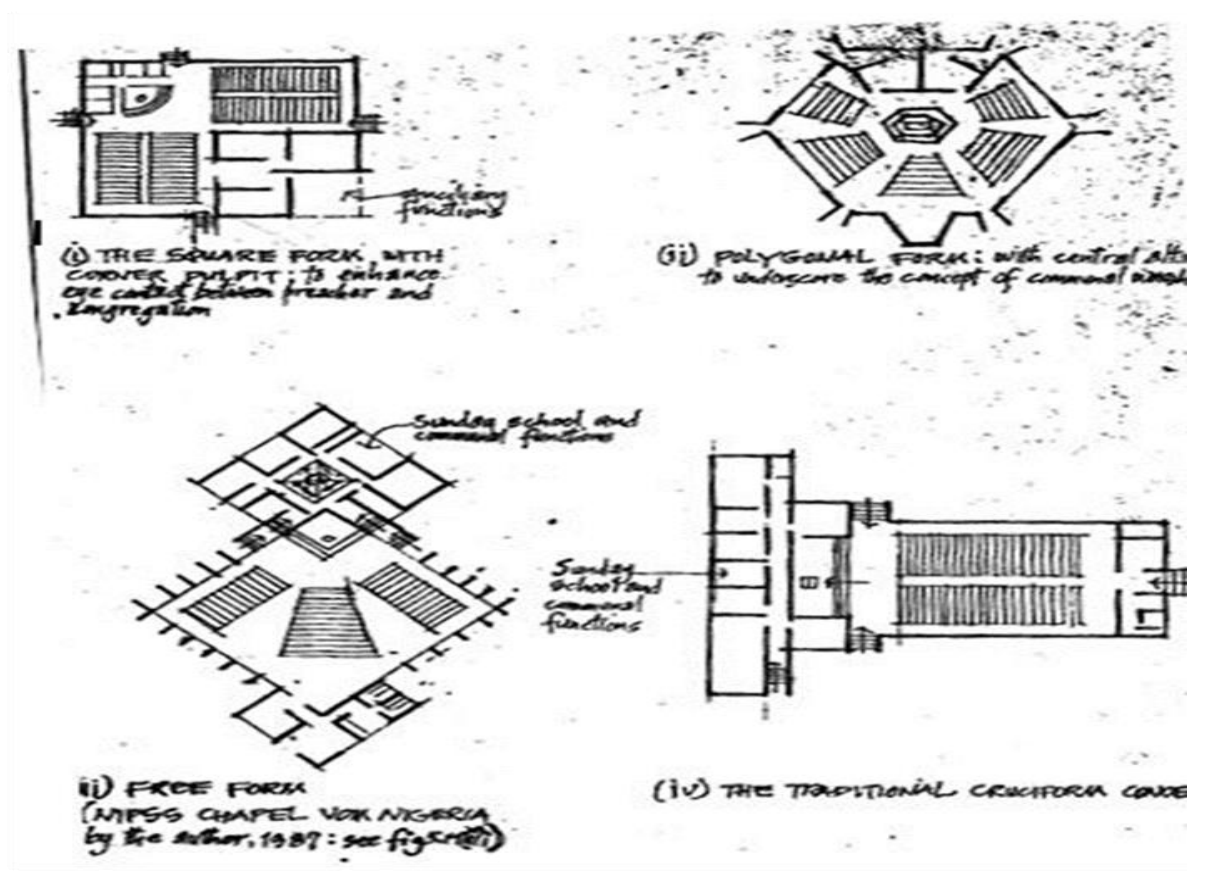

Figure: 1 Different forms of church buildings

(Source: Researcher's field work)

\subsection{Sound Quality}

Noise can be defined as an unwanted sound that is annoying or interferes with listening. Not all noise needs to be excessively loud to represent an annoyance or interference. Sound Quality here refers to good feelings that listeners have when being physically close to the performing group (the Choir in this case) or the speakers in Churches because of the mixing of sounds from all the performers and their uniform distribution to the listeners.

\subsection{Historical Review of Ecclesiastical Architecture}

Ecclesiastical Architecture can be grouped into:

(a) Basilica style: The word "basilica" has a Greek origin. It was formerly used to depict a Roman public building of rectangular shape with a large central hall. The basilica style (313 Ad 800 Ad) evolved in the 4th century AD from already existing roman architecture. The Roman basilica was formerly used for markets, meetings and courts of law but after Christianity became paramount in the Roman Empire, the basilica became a place of worship due to the presence of large internal space where the congregation could meet. 


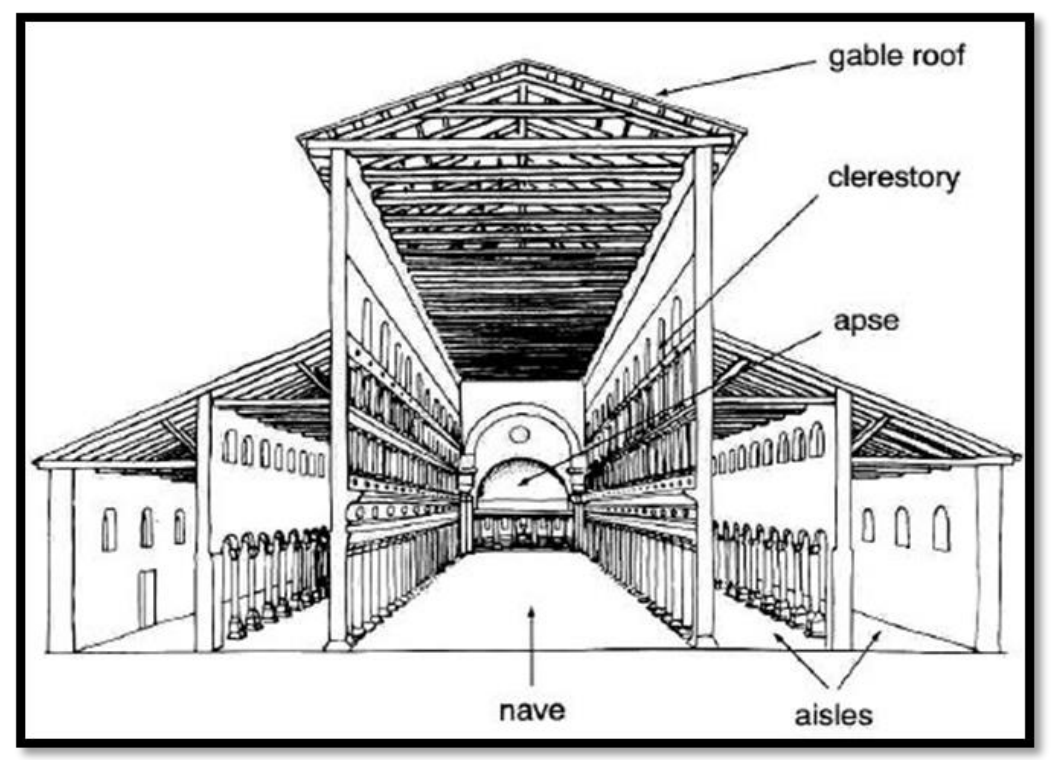

Figure 2: Reconstruction of the nave, Old St.Peter's Basilica in Rome (Source: http://www.phs.poteau.k12.ok.us/williame/APAH/readings)

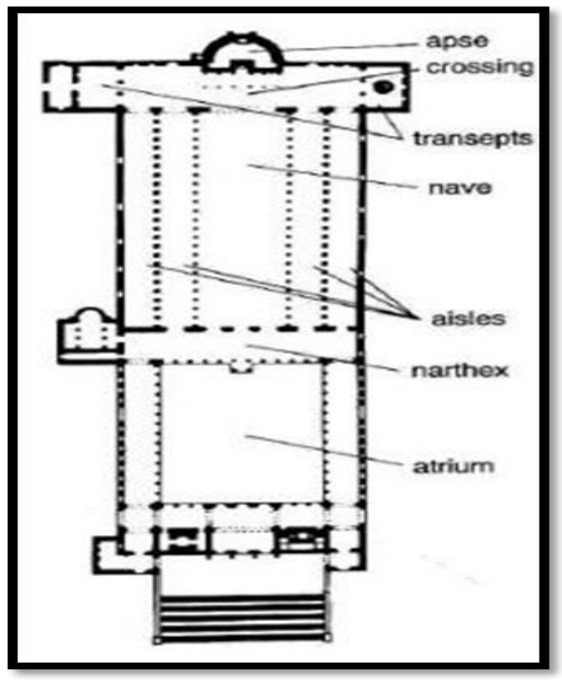

Figure 3: Plan of Old St. Peter's Basilica

(Source: http://www.phs.poteau.k12.ok.us/williame/APAH/readings)

(b) Byzantine style: The byzantine style also evolved in the 4th century (330AD-453AD). The style was developed in byzantine, the ancient empire of Constantinople (now turkey). Architect Justinian was responsible for the byzantine movement. Justinian was following in the footstep of Constantine the Roman emperor who converted to Christianity and elevated it to the level of a state religion. Justinian was focused on realizing Constantine's vision of a united Christian empire. He chooses not to unify his empire by force of arm instead (Gothic Architecture) he began an ambitious building project, constructing churches all over his empire. 


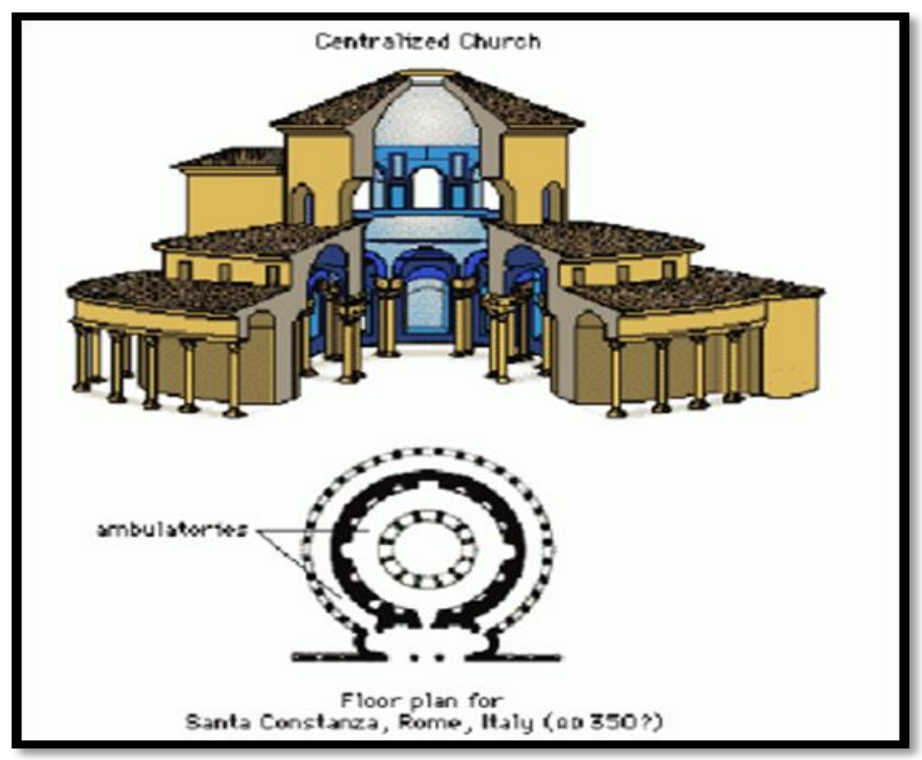

Figure 4: A Byzantine style of Church building, Santa Constanza, Rome, Italy (Source: http://archives.evergreen.edu/webpages/curricular/2006-2007/greeceanditaly/centralizedchurch-byzantine-style by Haftr 2007

(c) Romanesque style: The Romanesque style reigned during the 800AD and 1100AD. It was influenced by the previous styles such as byzantine (http://www.medieval-life-and-times.info). The layout was developed from the rectangular basilica style into a crucifix pattern of a nave, transepts and the apse. This movement made use of the Semi-circular arch, Barrel vault, Groin vault and the Ribbed vault.

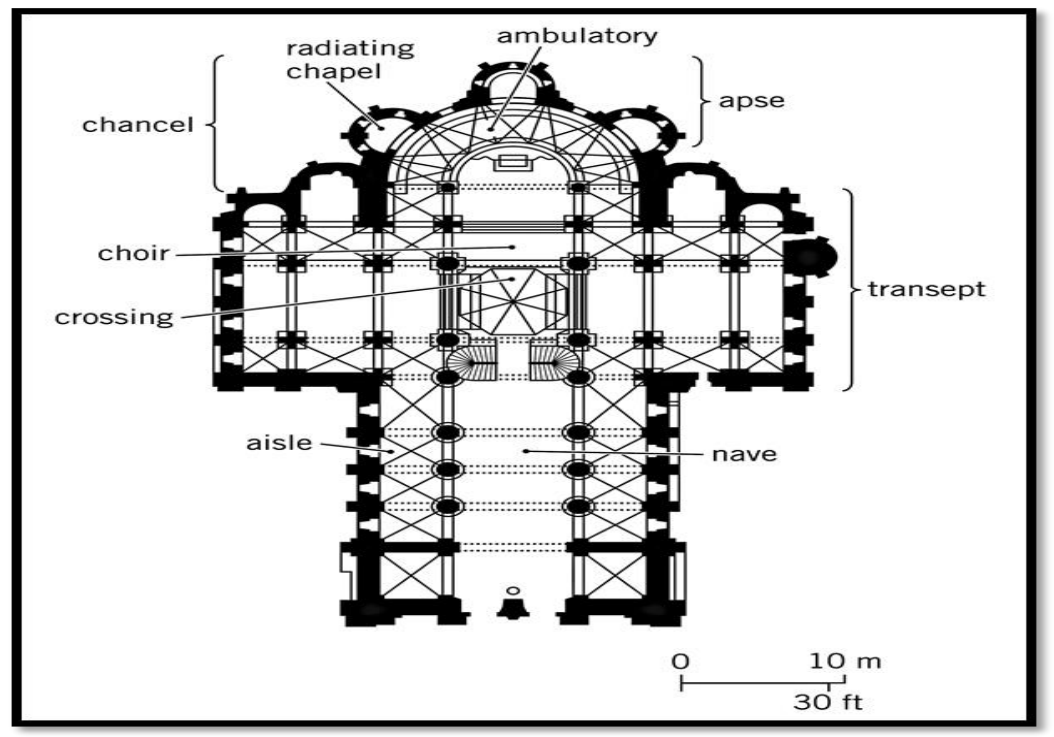

Figure 5: Floor plan of a Cathedral design

(Source: https://kmjantz.wordpress.com/2014/03/04/church-life-in-the-middle-ages/ by Sayre 2013)

(d) Gothic style: Gothic Architecture evolved as a result of common architectural problems in medieval times. This period was characterized by grand, tall designs which swept upwards with height and grandeur, the flying buttress, the pointed arch, the vaulted ceiling, the light and airy interior, the gargoyles, the emphasis on the decorative style and the ornate. 


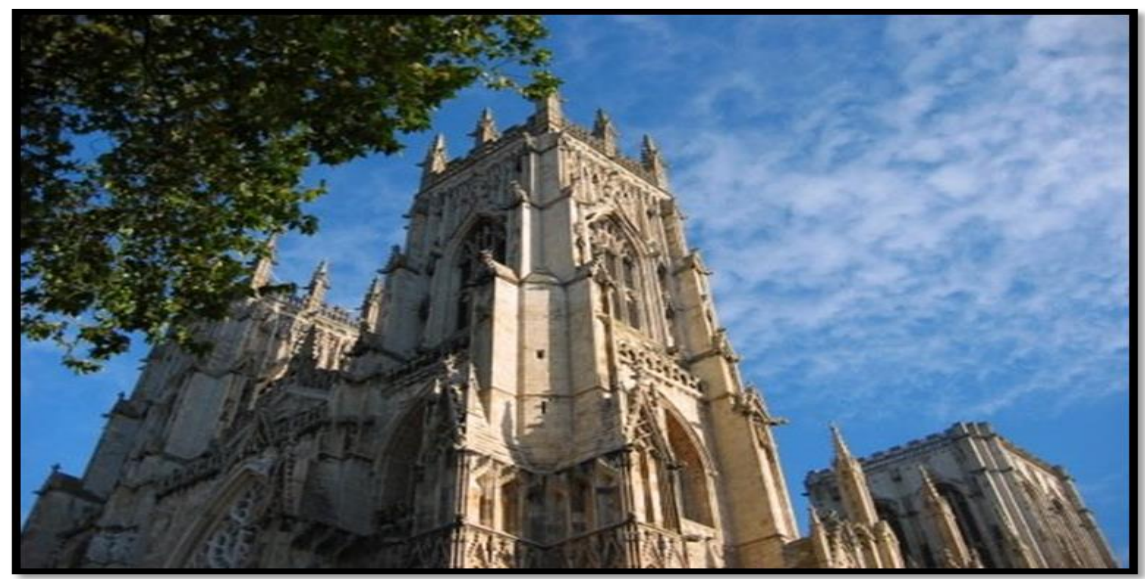

Figure 6: The Magnificent Gothic exterior of York Minster in the UK (Source: http://www.exploring-castles.com/characteristics_of_gothic_architecture.html by M. Poudal)

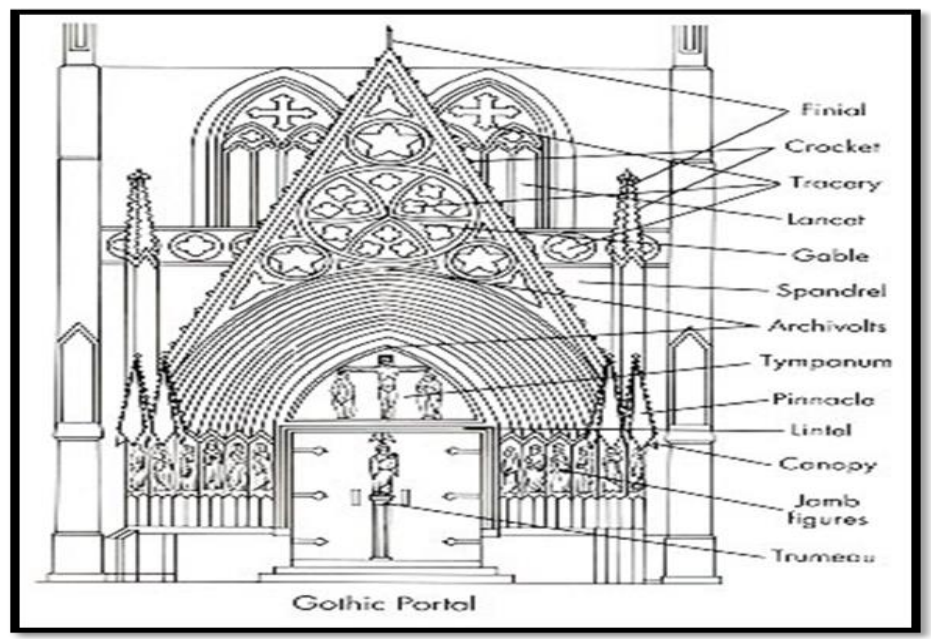

Figure 7: A typical Gothic Portal

(Source: http://www.cbcurtis.net/benedict/Humanities\%20Site/med_gothic_architec.html)

(e) Renaissance style: The word Renaissance literally means "rebirth". The Renaissance churches were built in Italy and north of the Alps. This period was characterised by an increase in the belief that mankind is God's creation. Similar to Renaissance art, the churches were born of a study of Roman antiquity, thus they consist of rows of columns, domes, and lucid arcades. The interior and exterior spaces of the church building were clearly defined, the designs of these areas were carved out and great emphasis was laid on mathematic geometry, a symbol of man's reason expressing God's order.

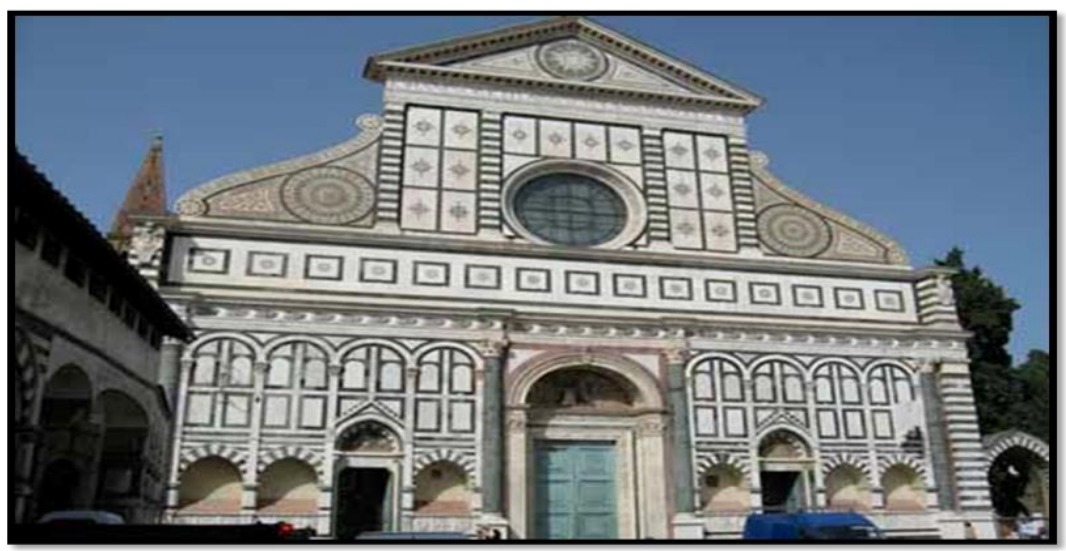

Figure 8: The façade of Santa Maria Novella, a Renaissance Church building designed by Alberti (Source: http://jtpennington.com/italy/page/5/ by Italy_JT, 2008) 


\subsection{Modern Architecture of Churches}

In the 19th century AD the effect of industrial revolution spread from Britain across Europe and America.

The church at Le Raincy near Paris designed by Auguste Perret is cited as the beginning of the process, not just because of the plan but also the materials used such as reinforced concrete. Modern architecture involves simplicity in form and design; it is free from jumble and unneeded elements. It tends to create designs that are inspired by function. Modern architecture replaced the traditional solidity of architecture by exposing the true nature buildings. Materials are shown in their natural form, structural elements are revealed to show the support and structure (Church Architecture, 2016).

\subsection{History of Christianity in Nigeria}

The Nigerian population is occupied with about $40 \%$ to $49.3 \%$ of Christians which is dominant in the southern part of Nigeria compared to the north. Nigeria has the largest population of Christians in Africa according to Pew Research Centre. The Christian population in Nigeria has being estimated to be about 85million, comprising of different churches.

(Ogunrinade \& Ogbole, 2013) posits that Christian origin in Nigeria could be dated to the Fifteenth Century. Nigeria was exposed to Christianity as a result of the desire of British merchants to trade on the coast of West Africa. This was after the discovery of the source of the Niger in 1830. The first visit was in 1841 and two members of CMS (Church Missionary Society) were present. Samuel Ajayi Crowther was one of them; he was then a teacher at Freetown. He was chosen because he was a Yoruba man from western Nigeria. Although the expedition failed, the Church Missionary Society was impressed with Samuel Ajayi Crowther ability. Shortly after, he was trained and ordained in England. He came back to Nigeria with Henry Townsend and began the Yoruba mission on the request for Christian Teachers by the liberated slaves (Erivwo, 1979).

However, Reverend Townsend and Reverend Thomas Birch-Freeman of the Methodist faith first preached the Christian Gospel to the inhabitants of Badagry under an Agia tree. This tree grew for 300 years, to a height of 160feet. The first Christmas service was held under the shade of this tree in 1842 . The tree was eventually blown down by a storm at about 11:45pm on Saturday, 20th of June 1949.

The first church building was built in memory of Reverend Henry Townsend and Reverend John B. Wood.

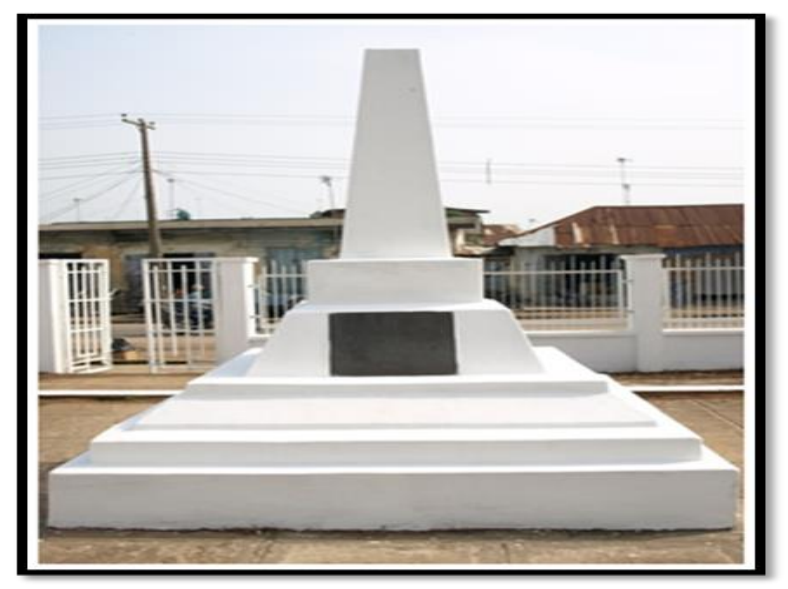

Figure 9: A monument erected in the place of the Agia tree (Source: http://akranofbadagrypalace.org.ng/our_people.aspx) 


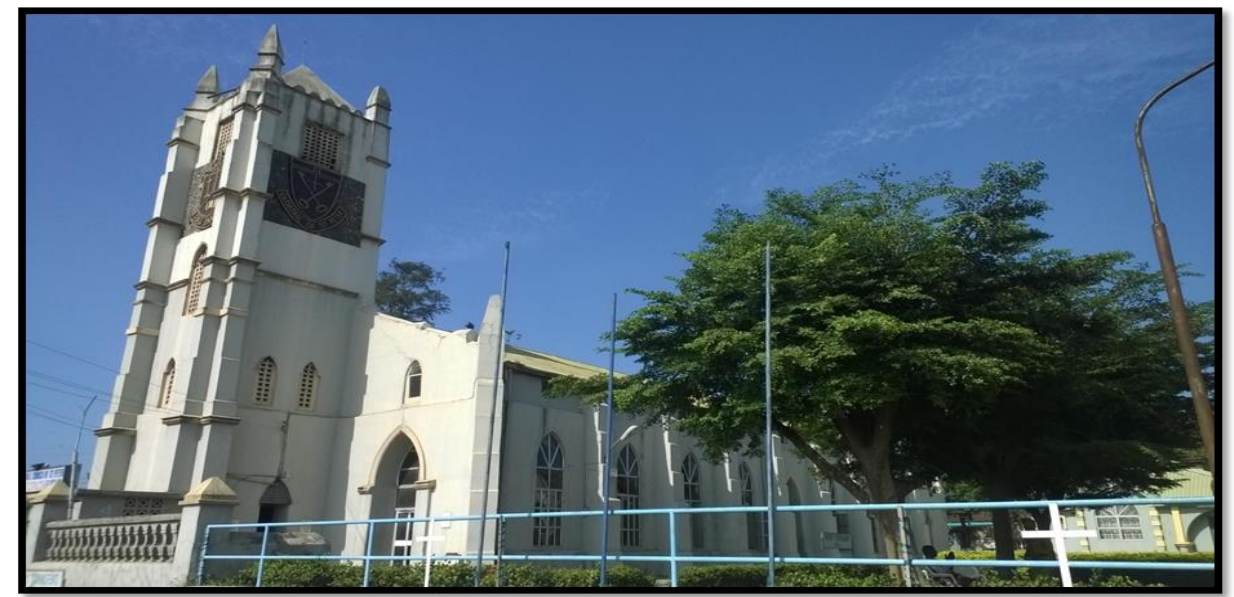

Figure 10: The first church building in Nigeria, the Cathedral of St. Peter Church in Abeokuta (Source: http://www.nairaland.com/ by Codedrock 2015)

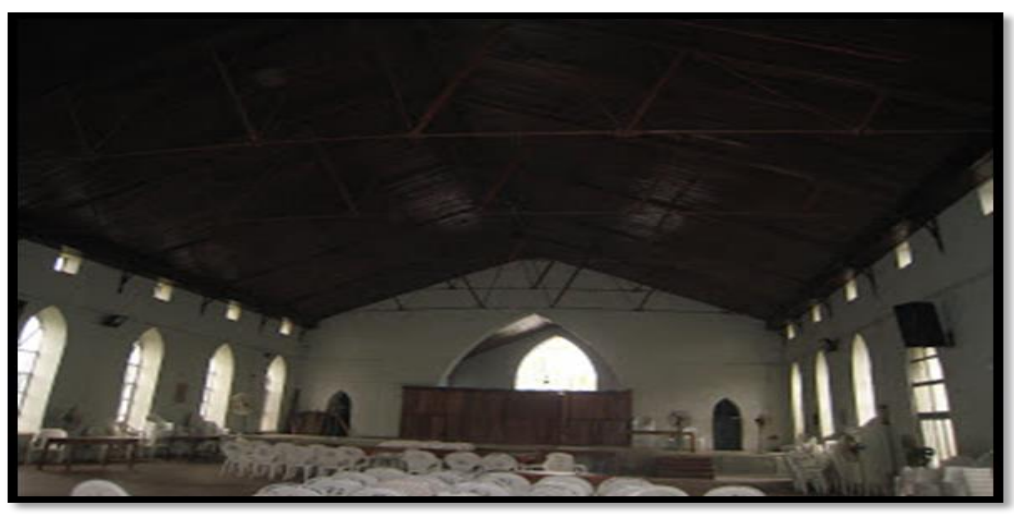

Figure 11: The interior of the first church building in Nigeria (Source: http://newhomeinlagos.blogspot.com.ng by Bod and Lisa 2009)

\subsection{Categories of churches}

There are 3 major types of Churches. This is as a result of diversity in the denominations; this also determines the Architecture of the church. The categories are as follows:

(a) Contemporary Churches

(b) Traditional Churches

(c) African Christian Churches

(a) Contemporary Churches: Contemporary churches can be seen as churches that worship in a way that is appropriate and meaningful for people who are living now, rather than people who lived 100 years ago or who will live 100 years in the future (United Methodist News Service, 2013). The design of these churches does not follow an existing style but emerge as a result of the Architects creativity and also the fact that there is no specific doctrine followed, unlike the Catholics. In other words, the designs are a result of the flexible mode of worship of the congregation. Churches under this category are the Pentecostals formerly known as the Protestants. These churches do not have historical precedent as they do not belong to any mother church. They are free form churches; examples are very numerous. 


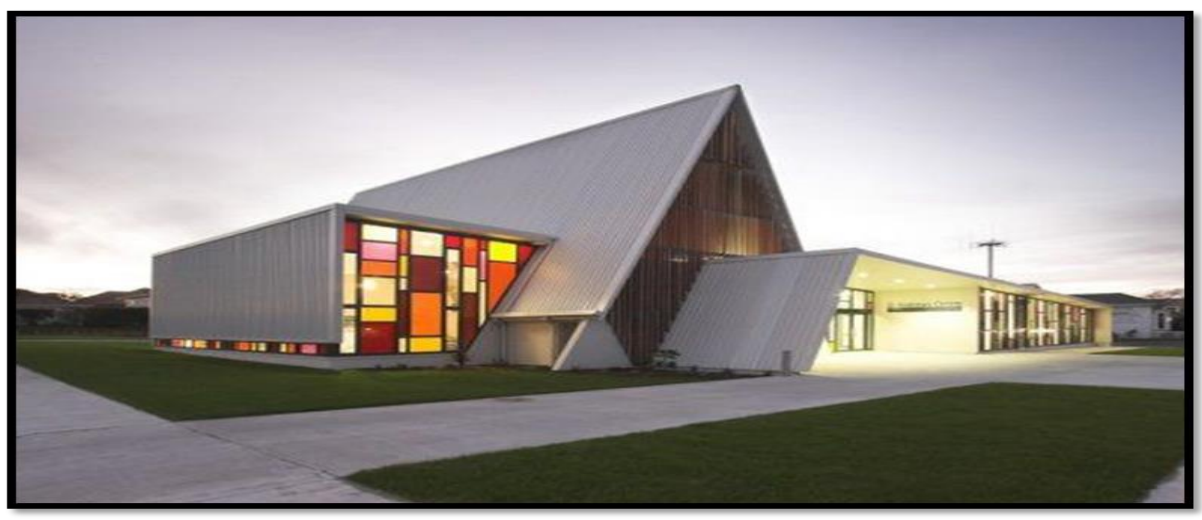

Figure 12: An example of a contemporary church

(Source: http://freshome.com/2009/11/22/waiuku-church-in-new-zealand-an-ingenious-architectureplan/)

(b) Traditional Churches: Traditional describes the generally held understanding of the local church. They are churches that have their design modelled after the styles of Ecclesiastical architecture listed previously. Churches in this category have great historical precedents; they tend to be program-oriented, event-oriented or purpose oriented in their identities. Their unique mode of worship defines and determines their interior design and planning pattern. Their façade is usually a reflection of the period they were founded. Examples in this category are the modern version of the gothic cathedrals which belong to the Anglican Communion and the Romanesque cathedrals, similar to the Roman Catholic Church and the Holy Aruosa Cathedral Benin city, particularly where the Benin Monarch worship God. These modern cathedrals are an expression of their origin which is usually referred to as their mother church.

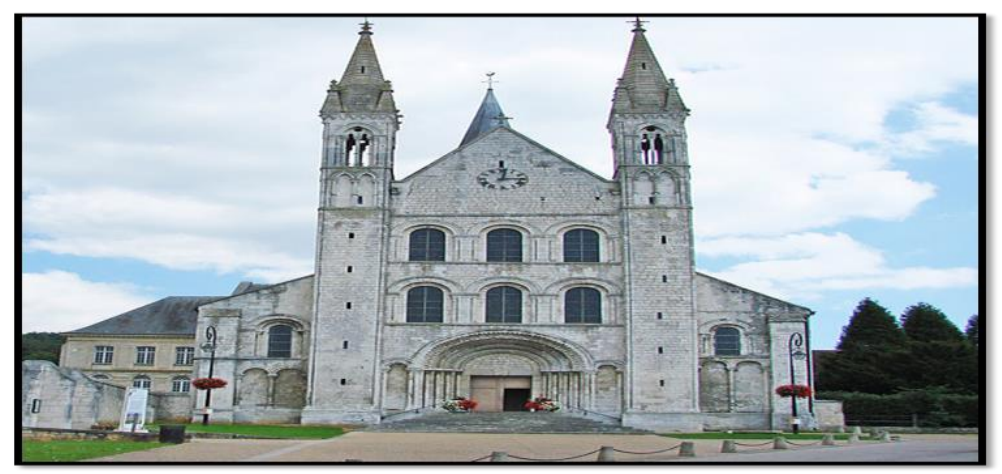

Figure 13: An example of a traditional church

(Source: https://en.wikipedia.org/wiki/List_of_regional_characteristics_of_Romanesque_churches)

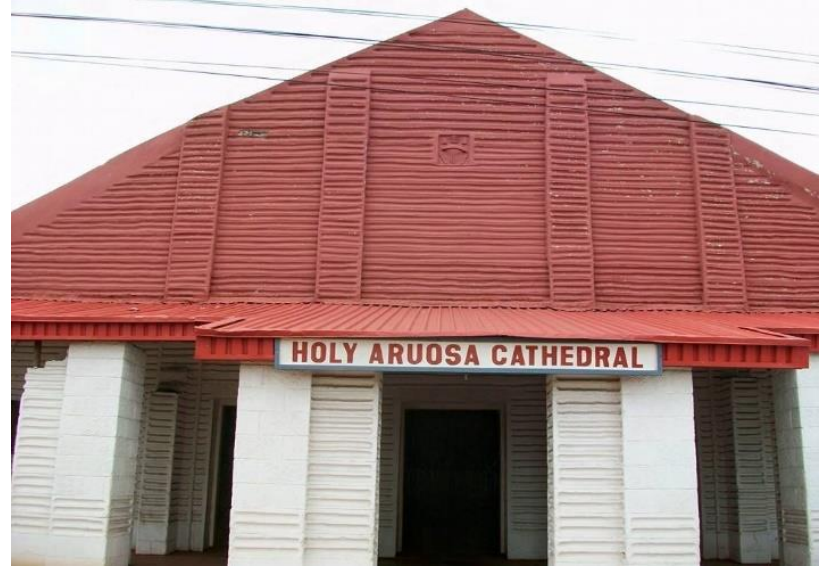

Figure 14: The Holy Aruosa Cathedral, Benin City. Built 1849.

(Source: http://www.nairaland.com/2817) 
(c) African Christian Churches: These churches are by Africans for Africans. They include the Celestial Church of Christ, the aladura, the Cherubim and Seraphim. According to Sensagent dictionary Aladura (Church of the Lord) meaning "owners of prayer" or "prayer fellowship" or "the praying people" is a Christian movement amongst the Yoruba people. It was founded by the first primate and late Prophet Dr. Josiah Olunowo Ositelu in 1925, but inaugurated in 1930 in Ogere Remo, Ogun State, Nigeria. This doctrine emphasizes power in praying and they believe in faith healing. The aladura movements in itself consist of various independent groups with different view point and practices, which distinguish them from each other. The movement includes churches like the salam church, idapoemimu church (aladura), to mention a few.

The Celestial Church of Christ started on 29th of September 1947 in Porto Novo, the Republic of Benin through the founder of the church, the Reverend, Pastor, Prophet, Founder Samuel Bilehou Joseph Oshoffa (1909-1985). They also believe in the power of prayer and bathing in a pool or stream (as means of healing or getting delivered from demons' possession, obsession and oppression). Thus, their churches are mainly large free flowing spaces without sitting arrangements.

\subsection{Research Method}

This research was carried out using the Qualitative and case study approaches. The qualitative method involves the collection of narrative data in a natural setting, with a view to gaining insight. The result gotten was presented in descriptive form. While the case study method involved an intensive study of specific phenomenon through investigations. These methods were chosen due to the nature of this research. In order to carry out this research effectively, fieldwork, observations and interviews were carried out on existing Churches to have and in-depth understanding of the subject matter. The case studies were picked using purposive sampling.

\subsection{Research Findings}

\subsection{Acoustics in large Halls Design}

Acoustics is an important issue because the Church building is used by a lot of people. The congregation should be able to hear the preacher clearly without disturbance. People also need to communicate within a space without their voices echoing. In Churches these days, adults and teen activities seem to require a lot of privacy, hence the need for an effective acoustic design within the different spaces in the Church building. The word acoustics is derived from a Greek word akouein, to hear (Rossing, 2007). It could also be seen as the qualities that determine the ability of an enclosure to reflect sound waves in such a way as to produce distinct hearing. Justiniano (2011) posits that the history of acoustic design in buildings began with the construction of amphitheatres by the ancient Greeks. These open air amphitheatres housed up to 2000 people, all listening to a single orator or small group of actors.

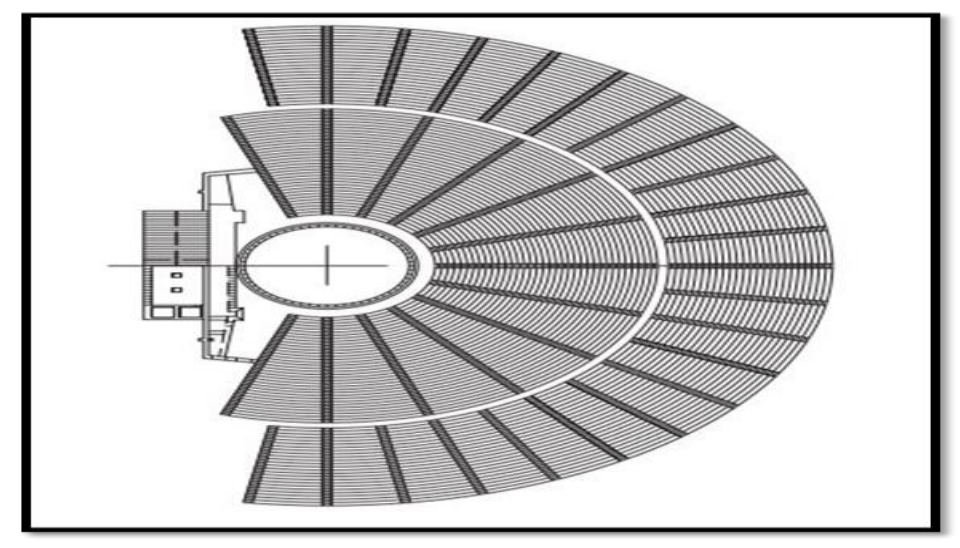

Figure 14: An ancient Theater at Epidaurus, Greece (Source: Izenour, 1977) 


\subsection{Sound Generation and Propagation in Church Buildings}

When sound is generated in a space, it moves and spreads in all direction by air, otherwise referred to as propagation of sound (SlideShare, 2013). Sound can be propagated from its origin to all directions because of the following principles: first, the propagation of sound depends on the frequency of the origin (sound source) and the capacity of the listener ear drum, second propagation of sound depends on the weather condition like air velocity, air temperature, presence of moisture and third the propagation of sound also depends on the environment by which it travels, that is the topographical feature. This involves the presence of hills and obstacles between the source and the receiver. It also includes the type of space whether open or closed.

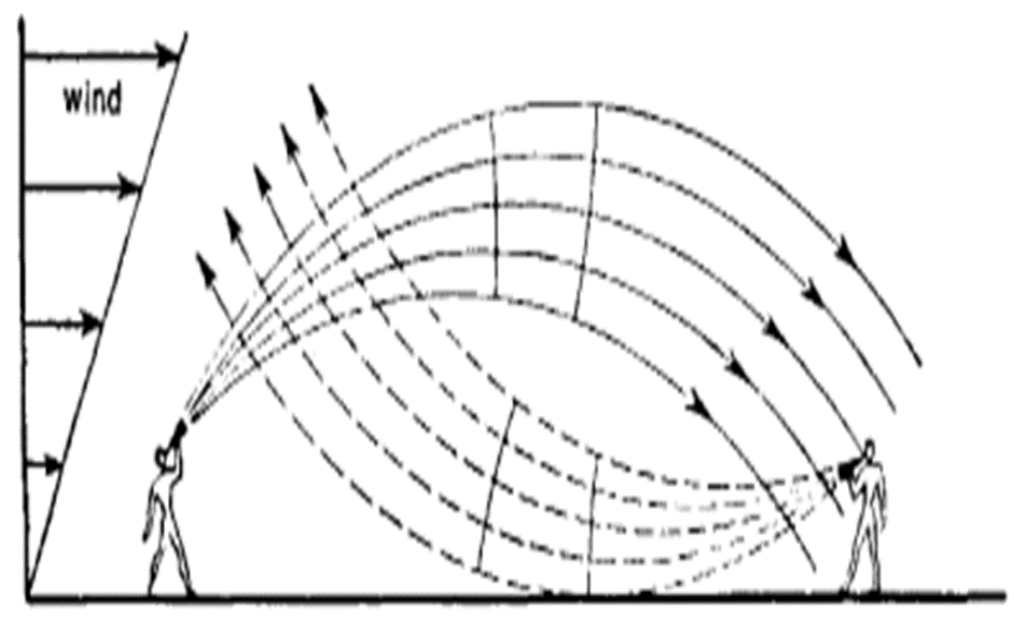

Figure 7: A diagram of Sound Propagation under the condition of an increase of wind with height (Source: from http://encyclopedia2.thefreedictionary.com/Acoustics+of+Moving+Media)

\subsection{Acoustics Characteristics}

Many of the acoustic characteristics of rooms and auditoriums can be directly attributed to specific physically measurable properties. Because the music critic or performing artist uses a different vocabulary to describe these characteristics than does the physicist.

\subsection{Room Acoustics and Design Shape}

It is important to note that concave reflective surfaces should be avoided for any use. If these types of surfaces must be used, it is best to provide the concave shape with acoustically transparent cloth covering absorptive or diffusive materials. Absorptive spray on material can be used on domed ceilings. Absorptive materials should be used when a reduced reverberation time is desired in a larger room (e.g., for lectures) and diffusive materials should be used when an enhanced reverberation time is desired in a smaller room (e.g., for cathedral music).

Table 1: Design tools for Different Building Shapes (Source: Acentech \& Cowan, 2000)

\begin{tabular}{|l|l|l|l|}
\hline Wall shape & design consideration & potential problems & Solution \\
\hline Flat & $\begin{array}{l}\text { Reflective surfaces can cause } \\
\text { acoustic anomalies }\end{array}$ & $\begin{array}{l}\text { Echoes, uneven } \\
\text { sound spreading }\end{array}$ & $\begin{array}{l}\text { Angle walls to direct sound to audience; use } \\
\text { absorptive or diffuse materials on walls that } \\
\text { would cause 100ft path delay }\end{array}$ \\
\hline $\begin{array}{l}\text { Parallel flat } \\
\text { walls }\end{array}$ & $\begin{array}{l}\text { Reflective surfaces can } \\
\text { Cause acoustic anomalies }\end{array}$ & $\begin{array}{l}\text { Echoes, flutter } \\
\text { echoes, standing } \\
\text { waves }\end{array}$ & $\begin{array}{l}\text { Avoid parallel reflective wall or treat one wall } \\
\text { with absorptive material. }\end{array}$ \\
\hline Concave & $\begin{array}{l}\text { Minimize reflective domes } \\
\text { and other concave reflective } \\
\text { surfaces. Hot and dead spot. }\end{array}$ & $\begin{array}{l}\text { Either eliminate dome and concave surfaces, use } \\
\text { absorptive spray on material, or cover absorptive } \\
\text { material with concave, acoustically transparent } \\
\text { material. }\end{array}$ \\
\hline $\begin{array}{l}\text { Convex or } \\
\text { uneven }\end{array}$ & $\begin{array}{l}\text { Allow for even spreading of } \\
\text { sound (diffusion) }\end{array}$ & $\begin{array}{l}\text { Excessive } \\
\text { reverberation }\end{array}$ & Add absorption to room surfaces. \\
\hline
\end{tabular}




\subsection{Implication/Conclusion}

The solution to these problems requires electronic modification of the sound reinforcement system and acoustical modification of the materials covering the walls, floor and ceiling. When someone mentions the term "acoustical material", unfortunately, most of us think of sound absorbing substances. These materials absorb or attenuate sound by converting the acoustical energy into heat. The walls, ceiling and floor in your worship space are flat or curved surfaces that offer a second type of sound modification refer to as reflection. Certain acoustic problems often result from improper design or from construction limitations. If large echoes are to be avoided, focusing of the sound wave must be avoided. Smooth, curved reflecting surfaces such as domes and curved walls act as focusing elements, creating large echoes and leading to bad texture. Improper blend results if, sound from one part of the ensemble is focused to one section of the audience. In addition, parallel walls in an auditorium reflect sound back and forth, creating a rapid, repetitive pulsing of sound known as flutter echo and even leading to destructive interference of the sound wave. Resonances at certain frequencies should also be avoided by use of oblique walls.

Acoustic shadows, regions in which some frequency regions of sound are attenuated, can be caused by diffraction effects as the sound wave passes around large columns and corners or underneath a low balcony. Large reflectors called clouds, suspended over the performers, can be of such a size as to reflect certain frequency regions while allowing others to pass, thus affecting the mixture of the sound. External noise can be a serious problem for halls in urban areas or near airports or highways. One technique often used for avoiding external noise is to construct the auditorium as a smaller room within a larger room. Noise from air blowers or other mechanical vibrations can be reduced using techniques involving impedance and by isolating air handlers.

Good acoustic design must take account of all these possible problems while emphasizing the desired acoustic features. One of the problems in a large auditorium involves simply delivering an adequate amount of sound to the rear of the hall. The intensity of a spherical sound wave decreases at a rate of six decibels for each factor of two increases in distance from the source, as shown above. If the auditorium is flat, a hemispherical wave will result. Absorption of the diffracted wave by the floor or audience near the bottom of the hemisphere will result in even greater absorption, so that the resulting intensity level will fall off at twice the theoretical rate, at about 12 decibels for each factor of two in distance. Because of this absorption, the floors of an auditorium should slope upward towards the rear.

\section{References}

Acentech, \& Cowan, J. (2000). Architectural Acoustics Design Guide. McGraw-Hill. Acoustical Glossary of Terms. (1980). Acoustical Surfaces Incorporated. Retrieved February 29, 2016, from http://www.acousticalsurfaces.com/acoustic_IOI/glossary.htm

Bruce Wardell architects. (2004). Short Church HIstory. Retrieved February 17, 2016, from NigerianWiki.com: http://nigerianwiki.com/wiki/Agia_Monument

Bob, \& Lisa. (2009). Life in Lagos, Nigeria and our Travels. Retrieved February 17, 2016, from http://newhomeinlagos.blogspot.com.ng/2009/07/abeokuta-fabric-market-1st-church-in.html

Codedrock. (2015). Retrieved February 17, 2016, from Nairaland Forum: http://www.nairaland.com/2501462/first-oldest-church-nigeria-gets

Erivwo, S. (1979). History of Christianity in Nigeria: The Urhobo, The Isoko and The Itsekiri.

Fowler, J. A. (2008). Christianity is not Religion. Fallbrook, California: C.I.Y. Publishing.

Haftr. (2007). Roman and Byzantine Art. Greece and Italy: An Artistic and Literary Odyssey. The Evergreen State College, Olympia, Washington. Retrieved February 16, 2016, from http://archives.evergreen.edu/webpages/curricular/2006-2007/greeceanditaly/centralized-churchbyzantine-style-and-baslicia-church-roman-style/index.html

Italy_JT. (2008). Viva La Italy. Retrieved February 16, 2016, from http://jtpennington.com/italy/page/5/ 
Justiniano, D. M. (2011). Scribd. Retrieved February 19, 2016, from http://www.scribd.com/doc/59706240/Acoustic-Design-Ppt\#scribd

Noxon, A. M. (2001). Understanding Church Acoustics. Retrieved February 8, 2016, from Acoustic Sciences Corporation Web site: http://www.church-acoustics.com/pdf/church-acoustics-booklet.pdf

Poruciuc., A. (2000). From Prehistoric Temples to Neo-Byzantine Churches. The Shape of Sacredness, pp. Volume 23, Issue 1.

Rossing, D. T. (2007). A Brief History of Acoustics. New York: Springer .

SlideShare. (2013). Basic Theory of Sound. Retrieved Febuary 29, 2016, from http://www.slideshare.net/seidadem/basic-theory-of-sound

Ugo, F. (2015). Wordpress.com. Retrieved February 17, 2016, from bantsandrants.wordpress.com: https://bantsandrants.wordpress.com/2015/10/27/weekend-vibes-the-badagry-slave-port/

Watson, D. C. (1978). I Believe in the Church. Great Britain: Hodder and Stoughton. Retrieved February 8, 2016, from NTRF Web site: https://www.ntrf.org/about-us/index.php

Watson, P. F. (1925). The Acoustics of The Moody Church. The Moody Church News, pp. Volume 10, Number 5. 